\title{
The anti-tumor effect and increased tregs infiltration mediated by $\mathrm{rAAV}$-SLC vector
}

\author{
Rilun Li $\cdot$ Heng Hu $\cdot$ Huiying Ma $\cdot$ Long Chen $\cdot$ \\ Shuang Zhou • Binbin Liu • Yinkun Liu • \\ Chunmin Liang
}

Received: 18 January 2013/ Accepted: 14 September 2013/Published online: 28 September 2013

(C) The Author(s) 2013. This article is published with open access at Springerlink.com

\begin{abstract}
To explore the anti-tumor effect and immune mechanism mediated by a new recombinant adeno-associated virus (rAAV) encoding secondary lymphoid tissue chemokine (SLC) mature peptide gene. AAV Helper-Free system was used for rAAV-SLC package. The anti-tumor effect of SLC was detected by bearing tumor established from Hepal-6 cells both in C57BL/6J and nude mice. Flow cytometry analysis and IHC for Tumor-infiltrating T cells and $\mathrm{CD} 11 \mathrm{c}+\mathrm{DCs}$ were also investigated to explore the immunological mechanism. rAAV-SLC was successfully packaged in AAV293 cells and transfected Hepal-6 tumor cells at high efficiency. The anti-tumor effect was demonstrated by less tumor weight and longer survival outcome. Coincident with the anti-tumor response, local elaboration of SLC within the tumor bed elicited a heavy infiltration of $\mathrm{CD}^{+}, \mathrm{CD}^{+} \mathrm{T}$ cells and $\mathrm{CD} 11 \mathrm{c}^{+}$dendritic cells into the tumor sites. More importantly, there was higher infiltration of Foxp3+ regulatory T cells (Tregs). Local elaboration of SLC mediated by rAAV-SLC has strong $\mathrm{T}$ cell mediated anti-tumor effect. The study also suggested that Tregs in the tumor microenvironment tampered the anti-tumor effect.
\end{abstract}

Keywords Recombinant adeno-associated virus . Secondary lymphoid tissue chemokine $\cdot$ Anti-tumor effect · Tregs

R. Li · H. Hu - H. Ma · L. Chen · S. Zhou - C. Liang ( $\)$ Department of Anatomy and Histology \& Embryology, Shanghai Medical College of Fudan University, 138 Yixueyuan Road, Shanghai 200032, People's Republic of China e-mail: cmliang@fudan.edu.cn

B. Liu · Y. Liu

Liver Cancer Institute of Zhongshan Hospital, Fudan University, Shanghai 200032, People's Republic of China

\section{Introduction}

Chemokines are small diffusible or matrix-associated proteins that transmit chemotactic signals into cells through pertussis toxin-sensitive, $G$ protein-coupled receptors. Among those chemokines, the chemokine secondary lymphoid tissue chemokine (SLC/CCL21) has been demonstrated to be unique one. It has been believed SLC and its receptor CCR7 play an important role in establishing the functional micro-environment in the secondary lymphoid tissues [1-12]. SLC is constitutively produced by high endothelial venules and by stromal cells within $\mathrm{T}$ cell zones of lymphoid organs. CCR7 is present on T cell subpopulations and is up-regulated by maturing dendritic cells and helps direct the immune effector cells to secondary lymphoid organs $[6,13,14]$. A spontaneous mouse line lacking SLC/CCL21 [15] and CCR7 knockout mice [16] show impaired homing of $\mathrm{T}$ cells into lymph nodes and Peyer's patches within the small intestine. In addition to CCR7, SLC also interacts with the CXCR3 receptor, through which block angiogenesis in vivo [17]. Previous work demonstrated that the chemotactic activity of SLC for DCs and $\mathrm{T}$ cells could be harnessed to generate antitumor immune responses [18-20]. Intratumoral injection of SLCgene-modified DCs resulted in more significant tumor growth inhibition [21]. It can be estimated that stronger response will be induced by attracting much larger numbers of effector T cells and APCs to the site of tumor, if a more efficient expression system established to produce SLC in tumor bed. The efficiency of an expression vector is one of the key aspects for gene therapy. Recently, it has been extensively demonstrated that recombinant adenoassociated virus (rAAV) are emerging nonpathogenic vectors with potential for cancer gene therapy. rAAV can successfully infect and transduce a broad variety of cell and 
tissue types, such as brain, liver, muscle, etc. [22-25]. Over the last several years, some in vivo studies using AAV have shown efficacious results in the treatment of multiple diseases in animal models and in human clinical trials $[26,27]$.

In this study, we evaluated the potential of rAAV as a vector for in vivo SLC gene modification of tumors and tested its antitumor properties.

\section{Materials and methods}

Animals

C57BL/6J $\left(\mathrm{H}-2^{\mathrm{b}}\right), \mathrm{BALB} / \mathrm{c}\left(\mathrm{H}-2^{\mathrm{d}}\right)$ and female nude mice, all 6-8 weeks of age, were purchased from Chinese Academy of Sciences and housed at the Animal Maintenance Facility of the Fudan University Shanghai Medical College.

\section{Medium and chemokine}

Complete medium consisted of RPMI 1640 with $10 \%$ heatinactivated FCS, $0.1 \mathrm{mM}$ nonessential amino acids, $1 \mu \mathrm{M}$ sodium pyruvate, $2 \mathrm{mM}$ fresh L-glutamine, $100 \mu \mathrm{g} / \mathrm{ml}$ streptomycin, 100 units $/ \mathrm{ml}$ penicillin, $50 \mu \mathrm{g} / \mathrm{ml}$ gentamicin, $0.5 \mu \mathrm{g} / \mathrm{ml}$ fungizone. Serum-free Opti-MEM I medium (GIBCO-BRL, Gaithersburg, Md.) Recombinant murine SLC was obtained from BIODESIGN (Saco,ME); Rat-anti-mouse SLC antibody was purchased from eBioScience company.

\section{Cell lines}

A mouse hepatocellular carcinoma cell line, Hepal-6 tumor cells (ATCC, catalog No: CRL-1830) were purchased from Chinese Academy of Sciences. AAV293 cells were purchased from Stratagen System Company.

\section{Production and purification of rAAV-SLC}

AAV Helper-Free system (Stratagene System Company, USA) was used for rAAV package. To amplify the fragments containing full coding region, the following specific primers of murine chemokine SLC was used. $5^{\prime}$ AGC GAA TTC TAC AGC TCT GGT CTC ATC CTC A $3^{\prime}$ (sense), cloned into EcoR I site; 5'GCG CTC GAG GTC TCT TTT CTA GCT CCC TCT TTG 3' (antisense), cloned into Xho I site. Total cellular RNA was extracted from lymph nodes from C57BL/6 J mice. The above fragments were amplified by RT-PCR (QIAGEN, Germany). After confirming the entire nucleotide sequence of PCR products, the EcoRI-XhoI fragment was inserted into the multiple cloning sites (MCS) of the pAAV-IRES-hrGFP vector, which contains the CMV promoter and AAV2 inverted terminal repeats (ITRs). rAAV-SLC serotype 2 vectors were prepared by using the three-plasmid cotransfection system. In addition, hrGFP expression was used to ascertain the transduction efficiency of the respective target. AAV293 cells were harvested $72 \mathrm{~h}$ post-transfection and lysed by repeated freezing and thawing. DNaseltreatment of viral preparations was performed to digest unencapsidated DNA, and Real-time Quantitative PCR (QIAGEN) analysis was used to determine the particle genome titer.

\section{Cy3-labeled viral transduction}

To investigate the infectious entry pathway of rAAV-SLC and assess AAV-mediated gene transfer, purified virus was labeled with the carbocyanine dye Cy3 (Amersham, NJ, USA). Hepal- 6 cells were infected with $1 \times 10^{11}$ particles/ $\mathrm{ml}$ of Cy3-conjugated rAAV $\left(\sim 10^{6}\right.$ particles/cell $)$ in binding buffer (DMEM containing $2 \mathrm{mM}$ glucose, $10 \mathrm{mM}$ HEPES [pH 7.3], and $1 \%$ bovine serum albumin) at $37{ }^{\circ} \mathrm{C}$ unless otherwise noted. Cells were washed 3 times with binding buffer prior to infection. Prior to fixation, the binding buffer was removed and the cells were washed 3 times again. Cells were then fixed with $4 \%$ paraformaldehyde in PBS for $15 \mathrm{~min}$ at room temperature and washed 3 times with PBS. Where indicated, cells were either treated for $5 \mathrm{~min}$ at room temperature with $1-\mu \mathrm{g} / \mathrm{ml}$ DAPI (Inc., Eugene, OR) in PBS with $0.1 \%$ Triton X-100 and washed 3 times with PBS or mounted in medium containing DAPI, which was used to indicate the position of the cell nucleus. Distribution of Cy3-AAV particles in Hepal- 6 cells at different time points (Control, $60 \mathrm{~min}, 2 \mathrm{~h}$, $12 \mathrm{~h}, 24 \mathrm{~h}, 72 \mathrm{~h}$ ) post infection was analyzed by confocal microscopy.

Twenty-four hours before transfection, Hepal-6 cells were plated in growth medium without antibiotics and grew to be approximately $80 \%$ confluent. The cells were washed once with serum free Opti-MEM I medium, and incubated with $100 \mathrm{MOI}$ of rAAV for different time points (control, $60 \mathrm{~min}, 2 \mathrm{~h}, 12 \mathrm{~h}, 24 \mathrm{~h}, 72 \mathrm{~h}$ ) at $37{ }^{\circ} \mathrm{C}$ with $7 \%$ $\mathrm{CO} 2$ with gentle agitation every $15 \mathrm{~min}$. After infection, cells were washed three times and then cultured in complete RPMI medium until further analyses.

Detection of SLC produced by Hepal-6 cells infected with rAAV-SLC

SLC expression of Hepal-6 cells post-transfection was confirmed by RT-PCR and specific ELISA. Supernatants were collected from Hepal- 6 cells with either rAAV-GFP or rAAV-SLC $48 \mathrm{~h}$ post-infection and stored in $-76{ }^{\circ} \mathrm{C}$ for further use. A chemotaxis assay was used to further determine the levels and the bioactivity of SLC produced in 

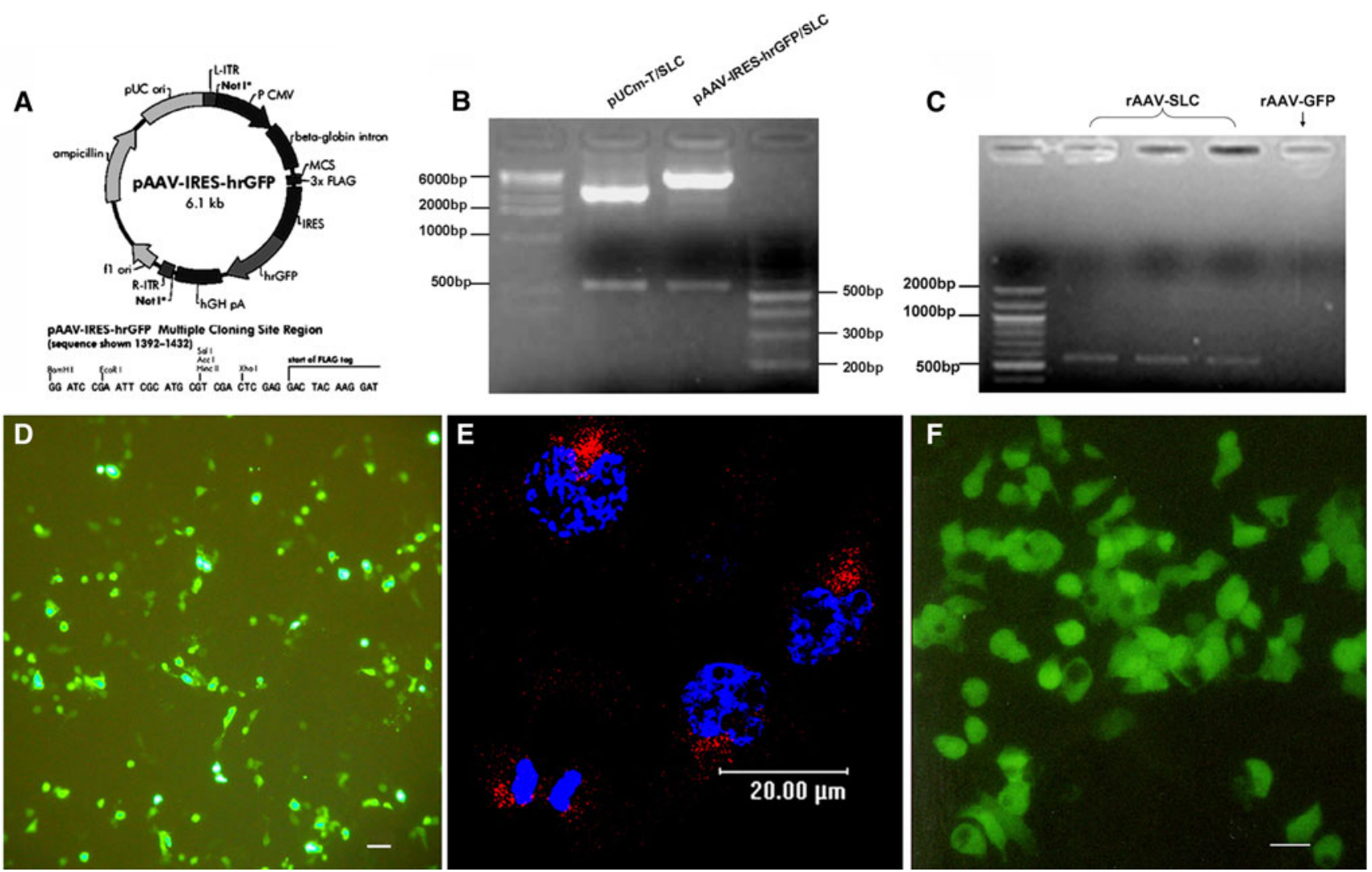

Fig. 1 rAAV-SLC was constructed and infected Hepal-6 cells at high efficiency. a The entire nucleotide sequence of SLC was cloned into the MCS of the pAAV-IRES-hrGFP vector; Positive clones were demonstrated by restriction digestion (b) and by PCR (c); (d) rAAVSLC was packaged in AAV293 cells by using the three-plasmid cotransfection system. GFP expression was served as a useful expression marker; e distribution of Cy3-rAAV-SLC particles (red) in

the supernatant of SLC-modified Hepal-6 cells. Supernatants from infected cells were added to the bottom chamber of 24-well plates with 6.5 -mm diameter, $5 \mu \mathrm{m}$ pore polycarbonate Transwell insets (Corning Coster, Cambridge, MA) in duplicate samples, as the source of chemo attractant in chemotaxis assays, with $\mathrm{T}$ cells $\left(10^{7}\right)$ being performed in the upper chamber as responder cells. At the same time, recombinant mouse SLC (100 ng/ml, BIODESIGN, ME) were added to the bottom chamber as positive control. $\mathrm{T}$ cells were purified from normal C57BL/6J mouse spleen using mouse $\mathrm{T}$ cell recovery column kit (Cedarlane, Ontario, Canada) according to the instructions of the manufacturer. For determining the number of cells, $10^{4}$ polystyrene beads (15- $\mu \mathrm{m}$ diameter; Bangs Laboratories, Fishers, IN) were added to the lower chamber previously. Samples were stained with antibodies against CD3 (for $\mathrm{T}$ cells) and counted on a FACS caliber (BectonDickinson, San Jose, CA). The percentage of migration in each sample (\% input) was determined from numbers of the starting cells and the migrated cells by the equation: $\left[\left(\right.\right.$ No cells ${ }^{\text {Sample }} /$ No cells $\left.\left.{ }^{\text {Input }}\right) \times 5\right] \times 100$.
Hepal- 6 cells $2 \mathrm{~h}$ post-transduction were observed to shift toward the nucleus and begin to accumulate at the nuclear envelope, detected by laser scanning confocal microscope. The position of the cell nucleus was assessed by DAPI (blue) staining. A representative image is shown, consisting of a single plane of focus through the center of a cell; $\mathbf{f} 72 \mathrm{~h}$ post-transduction, SLC expression in Hepal-6 cells were analyzed by fluorescence microscopy for GFP detection

Tumor establishment in C57BL/6J and nude mice

Hepal- 6 cells $\left(2 \times 10^{6}\right.$ cells $\left./ 200 \mu \mathrm{l}\right)$, infected by rAAVSLC or rAAV-GFP virus or noninfected as mock control were injected subcutaneously (s.c.) into the right flank of 6-8-week-old C57BL/6 J and nude mice. At the same time, intra-tumor (i.t.) injection of rAAV-SLC $\left(5 \mu \mathrm{l}, 0.6 \times 10^{9}\right.$ viral particles) into established tumors was studied. As previously indicated, the AAV viral vectors were delivered to six sites, $0.5 \mathrm{~mm}$ apart, along the needle track as the needle was withdrawn with a volume of $\sim 0.8 \mu \mathrm{l}$ at each of the six sites over $10 \mathrm{~min}$. The needle was left in the tissue for an additional $5 \mathrm{~min}$ and then was slowly withdrawn. Developing tumors were monitored every day for 45 days. Tumors were harnessed on the day of 20 and weighed.

Western blot analysis for SLC expression in the tumor sites

The harnessed tumor tissues were lysed with lysis buffer (RIPA) on ice. After centrifugation at $14,000 \mathrm{rpm}$ at $4{ }^{\circ} \mathrm{C}$ 
Fig. 2 rAAV induced potent antitumor effect in vivo. a In C57BL/6J mice and $\mathbf{b}$ nude mice, the local expression of SLC in tumor sites was analyzed by Western-blot assay; c, d SLC-producing tumors showed a delayed progression and restrained in tumor weight when compared to rAAV-GFP tumors. No difference was observed between GFPexpressing and mock background tumors; e, f SLCproduction was also associated with significantly improved survival. There was a worse survival in nude mice models, compared with C57BL/6J mice models. Bars SD, ** $p<0.01$ compared with rAAV-GFP group, $* p<0.05$ compared with rAAV-SLC group; i.t., intra-tumor injection
In C57BL/6J Mouse

A

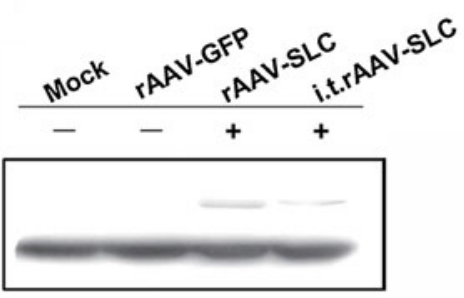

C

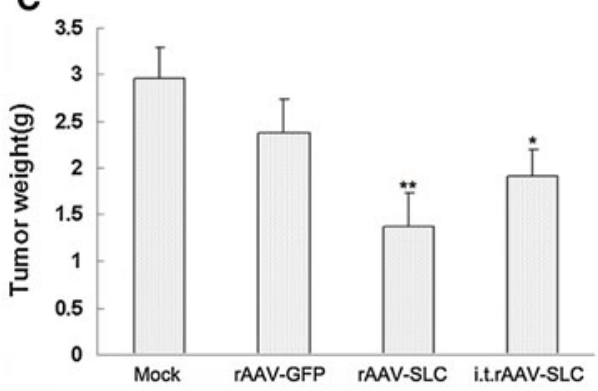

E

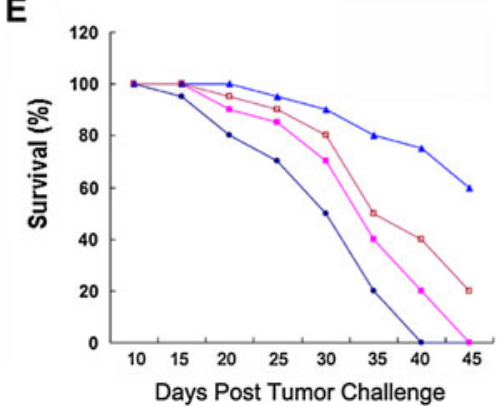

In Nude Mouse

B

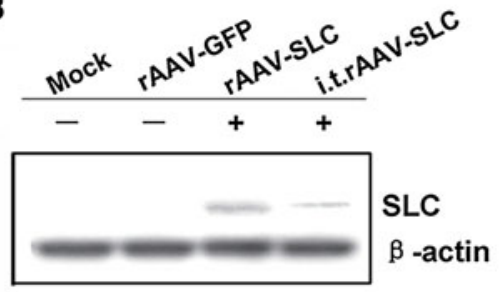

D

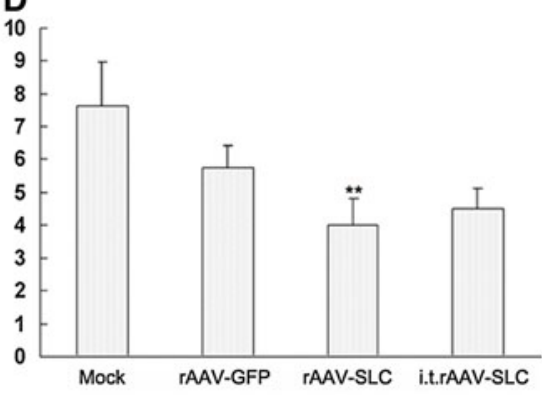

$\mathbf{F}_{12}$

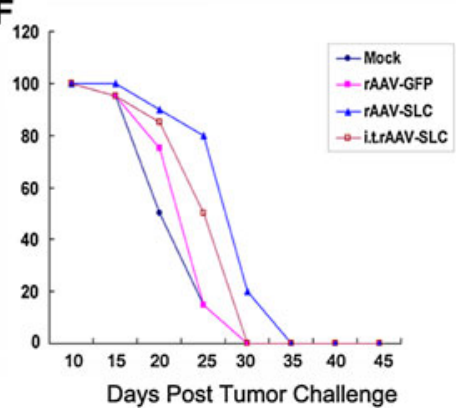

for $30 \mathrm{~min}$, supernatants were collected and total protein concentrations were determined by BCA assay (Pierce, Rockford, IL). Equal amounts of denatured proteins were loaded onto $10 \%$ SDS-PAGE gel and transferred on PVDF membrane (Millipore, Bedford, MA). Membranes were blocked with $5 \%$ nonfat milk in TBST $(1 \times$ TBS containing $0.1 \%$ Tween 20), then incubated with primary antibodies to SLC and $\beta$-actin (eBioScience, San Diego, CA) overnight, After three times washing with TBST, HRP-conjugated secondary antibodies (KPL, Gaithersburg, MD) were bound and performed with chemiluminescence using SuperSignal West Pico substrate (Pierce, Rockford, IL).

IHC and flow cytometry analysis of tumor-infiltrating $\mathrm{T}$ cells and CD11c+ DCs

For analysis of cells infiltration, some tumors were harvested, removed of extraneous tissues on the day 20. Half of each tumor sample was used for OCT embedding and Serial $5 \mu \mathrm{m}$-thick Cryostat sections were performed by incubation with mAbs (PharMingen, San Diego, CA, USA) recognizing CD11c+ dendritic cells, CD4+Tcells, CD8+T cells as well as Foxp3+Tregs. Isotype-matched antibodies were used as a control. The remaining half was digested for $2 \mathrm{~h}$ at room temperature in $1 \mathrm{mg} / \mathrm{ml}$ type IV collagenase (Sigma, USA) with constant stirring. Digested tumors were passed through a $70 \mu \mathrm{m}$ nylon mesh, washed once with HBSS, and resuspended in PBS/3\% BSA to $\sim 1 \times 10^{6}$ cells $/ \mathrm{ml}$. Polystyrene beads $(15-\mu \mathrm{m}$ diameter $)$ were added to the samples to achieve a concentration of $5 \times 10^{5}$ beads $/ \mathrm{ml}$. Samples were stained for the presence of FITC-conjugated CD25, PE-conjugated antibodies CD4, CD8, CD11c and Foxp3. Samples were analyzed by flow cytometry analysis with counting of 50,000 lymphocytesized events (based on splenocyte controls). The number of infiltrating CD4+ or CD8+cells was determined by the following equation: (No of PE-events/No of bead events) $\times 5 \times 510^{5} \times 5$ cell sample column .

Statistical analysis

Statistical analyses were performed with software from SPSS 10.0 for Windows, Inc. (Chicago, IL). Results were 


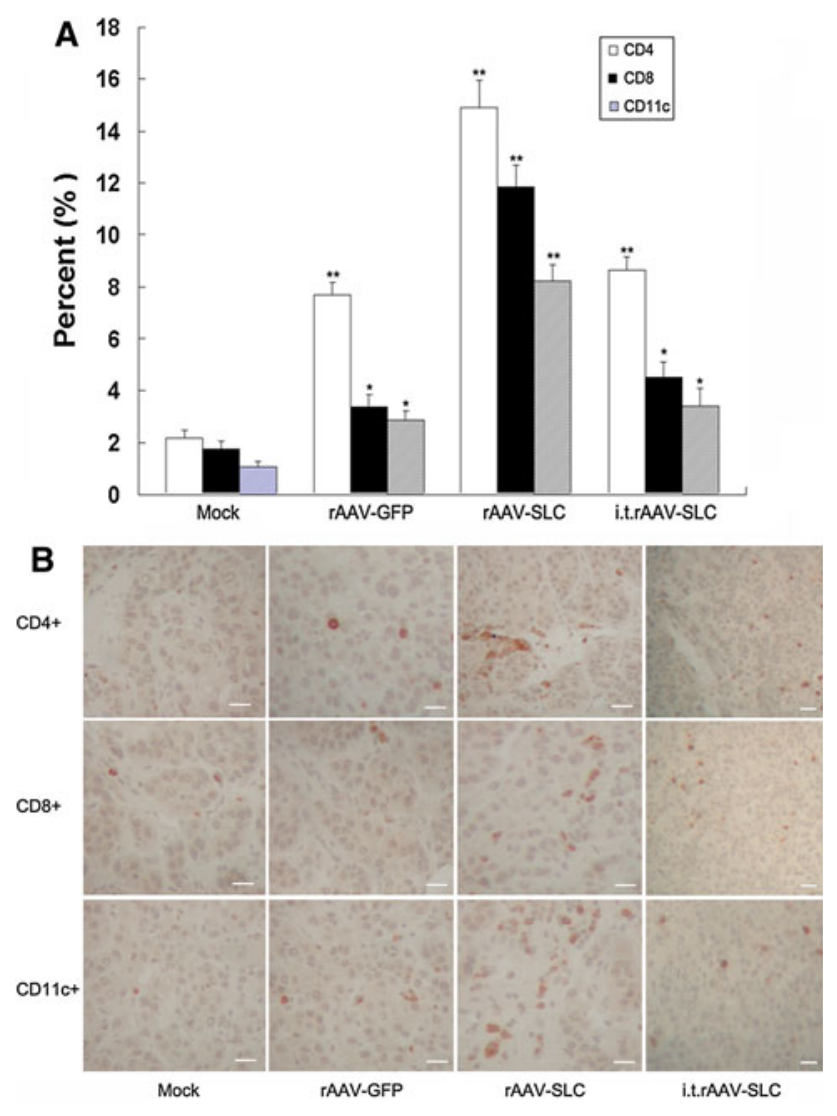

Fig. 3 The observed antitumor effect of rAAV-SLC was immunemediated. a The collected cells from tumor samples were stained FITC-CD11c, FITC-CD3 together with PE-CD4 or PE-CD8 for flow cytometric evaluation. Compared to control and rAAV-GFP, significantly higher numbers of CD11c+dendritic cells, CD4+T cells and $\mathrm{CD} 8+\mathrm{T}$ cells infiltration in SLC-treated mice were observed. Bars $\mathrm{SD}, * p<0.05, * * p<0.01$; i.t., intra-tumor injection; b serial $5 \mu \mathrm{m}$ thick Cryostat sections of tumor samples were performed by incubation with $\mathrm{mAbs}$ recognizing $\mathrm{CD} 11 \mathrm{c}+$ dendritic cells, $\mathrm{CD} 4+\mathrm{T}$ cells and CD8+T cells. Positive cells were detected by DAB staining

evaluated by Student's $t$ tests. A $P$ value $<0.05$ was taken as the level of significance.

\section{Results}

High transduction efficiency of liver cancer cells using rAAV-SLC

AAV Help-Free System was used for the package of rAAVSLC. Firstly, the entire nucleotide sequence of SLC was cloned into the MCS of the pAAV-IRES-hrGFP vector. Positive clones was demonstrated by restriction digestion and PCR, as shown in Fig. 1a-c. As followed, a new rAAV 2 encoding SLC peptide (rAAV-SLC) was successfully packaged in AAV293 cells by three-plasmids co-transfection system, as shown in Fig. 1d, $72 \mathrm{~h}$ post-transfection, the virus particles was harvested. Virus titer was $1.25 \times 10^{11}$ analysed by Real-time PCR, which was used to infect Hepal-6 cells later, with GFP as a marker of gene expression. Hepal-6 cells are highly susceptible to rAAV-mediated transduction. $2 \mathrm{~h}$ post-transfection the viral particles were observed to shift toward the nucleus and begin to accumulate at the nuclear envelope (Fig. 1e). $72 \mathrm{~h}$ post-transfection, based on the expression the marker gene GFP, it was found that about $50 \%$ Hepal-6 tumor cells were positive in showing the transduction efficiency (Fig. 1f). There was no difference in transduction efficiency between the rAAV-SLC and rAAV-GFP. The control groups of single rAAV transduction have black background. The expression of SLC and its bioactivities were demonstrated in intro by ELISA and chemotaxis assay (Data not shown).

rAAV-SLC induced a potent anti-tumor effect

The local expression of SLC in tumor sites of tumor bearing mice models were analyzed by Western-blot assay, we found the local expression of SLC in the tumors established from Hepal-6 cell lines previously transfected by rAAV-SLC. There was lower level local expression of SLC in the group of intra-tumor (i.t.) injection of rAAVSLC into established tumors, as shown in Fig. 2a, b. The effect of rAAV-induced local expression SLC to enhance antitumor immune responses was subsequently tested. To elucidate in detail the mechanism of rAAV-SLC anti-tumor effect, we also examined its effect in nude mice. SLCproducing tumors showed an obviously delayed progression when compared to rAAV-GFP tumors $(p<0.01)$. rAAV-SLC had stronger anti-tumor effect compared with i.t.rAAV-SLC treated group $(p<0.05)$ in C57BL/6J mice. No difference was observed between GFP-expressing and normal background tumors, as shown in Fig. 2c, d. In parallel to reduced growth, SLC local expression was also associated with significantly improved survival as shown in Fig. 2e, f. The development of tumors was faster in nude mice than in C57BL/6J mice, and showed poorer survival.

Local expression of SLC promoted the recruitment of $\mathrm{T}$ cells and $\mathrm{DCs}$ to the tumors in vivo

Because SLC is chemotactic for T cells and DCs, we hypothesized that SLC expressed from tumor cells would elicit migration of these cells to the tumor site. To quantify the number of infiltrating CD4+ and CD8+T cell lymphocytes as well as CD11c+DCs were determined by flow cytometry and IHC analysis. These analysis illustrated that SLC-expression induced significantly higher numbers of $\mathrm{CD} 4+, \mathrm{CD} 8+\mathrm{T}$ cells and $\mathrm{CD} 11 \mathrm{c}+\mathrm{DCs}$ recruitment when compared to control $(p<0.01$, as shown in Fig. 3). A 


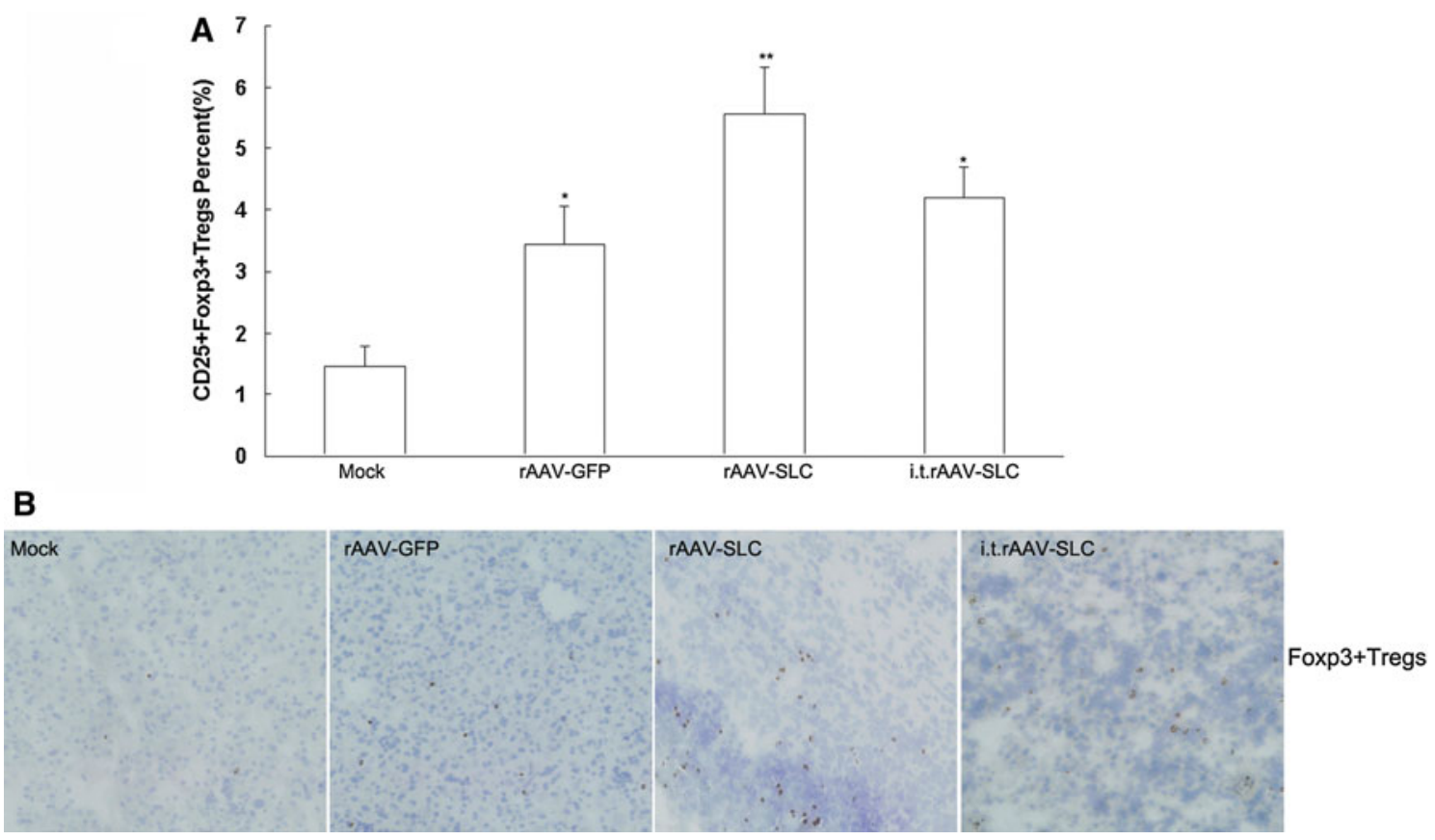

Fig. 4 More Foxp3+regulatory $\mathrm{T}$ cells (Tregs) in the tumor sites were detected by FACS and IHC. a The collected cells from tumor samples were stained with FITC-CD25, PE-Foxp3 for flow cytometric evaluation of Tregs. Compared to control and rAAV-GFP, significantly higher numbers of Treg cells infiltration in mice with rAAVSLC treatment. Bars SD, $* p<0.05$, $* * p<0.01$; i.t., intra-tumor

modest increase in infiltrated immune cells was also observed in rAAV-GFP pre-infected tumors.

Local expression of SLC also promoted higher infiltration of CD25+Foxp3+regulatory $\mathrm{T}$ cells (Tregs) in the tumor sites

In order to further explore the mechanism of SLC mediated anti-tumor effect, infiltrated CD25+Foxp3+Tregs in the tumor sites were also tested by FACS (Fig. 4a) and IHC (Fig. 4b). There were more infiltrated Tregs in the groups of SLC local expression $(p<0.01)$.

\section{Discussion}

In several studies, cytokine genes have been introduced into tumor cells in an attempt to provide a microenvironment that favors innate and acquired immune mechanisms to prevent or reverse tumor development [28]. In particular, chemokine gene transfer offers the possibility to trigger the recruitment of initiators or effectors of the immune response within the tumor $[29,30]$. The chemokine m6Ckine/SLC has been proposed to play a role in favoring the interactions between dendritic cells and $\mathrm{T}$ cells in secondary lymphoid organs, through its interaction with the CCR7 receptor [9, 12, 16, 31-33]. Previous works injection. b For IHC analysis of regulatory $\mathrm{T}$ cells infiltration, tumors cryostat sections were performed by incubation with mAbs recognizing Foxp3. Positive cells were detected by DAB. More Foxp3 positive cells were found in the tumor sites of mice with rAAV-SLC treatment

demonstrated that SLC chemotactic activity for DCs and T cells could be harnessed to generate antitumor immune responses [20, 34-38]. Almost all of the past reports showed that antitumor effect of SLC was mediated by greatly enhancing the tumor infiltration of mature dendritic cells and CD8+T cells [39-41].

We reasoned that such an activity would be additionally improved by in situ activation of recruited DCs and T cells via local expression of SLC. In this study, we applied rAAV vector to deliver SLC directly into the tumor cells for its broad host range, excellent safety profile, and the ability to integrate into the host genome as well as longterm expression in infected hosts [42, 43]. Different from other reports [21, 34, 38, 44], we harnessed long-term local elaboration of SLC in the tumor bed mediated by rAAV vector to detect its antitumor effect. We have shown that rAAV-SLC was more effective in generating systemic antitumor responses and was accompanied by extensive $\mathrm{CD} 4+, \mathrm{CD} 8+\mathrm{T}$ cells, as well as CD11c+DCs infiltrating into the tumor sites. This is consistent with previous studies. On the other hand, the results also suggest that SLC local expression in tumor bed plays another role in anti-tumor effect on destroying the solid tumor barrier by infiltrating extensive lymphocytes. The 'barrier' formed around solid tumors by infiltrating host stroma hinders the presentation of tumor antigens in DLNs and, in the absence of a robust co-stimulatory environment, specific $\mathrm{T}$ cells can 
remain ignorant $[45,46]$. Additional obstacles for $\mathrm{T}$ cell homing and expansion inside tumors may also prevent tumor eradication [47]. Murine models have shown that abundant, activated, tumor antigen-specific $\mathrm{T}$ cells fail to reject tumors even when they can reject skin grafts or less established tumors bearing the same antigen [48]. Thus, the tumor barrier may be an important contributor to the failure of tumor rejection. It is possible that the active recruitment of naive $\mathrm{T}$ cells into tumors, followed by their activation through robust co-stimulation and sufficient antigen load, may overcome these obstacles in antitumor immunity.

However, we also found there was higher infiltration of Foxp $3+$ regulatory T cells (Tregs) mediated by rAAV-SLC treatment. It has been thoroughly demonstrated that during the tumor development, tumor microenvironment (such as the secretion of TGF- $\beta$ and IL-10) can educate T cells into regulatory $\mathrm{T}$ cells (Treg) or more and more $\mathrm{T}$ cells became ignorant. Tregs are identified as a small proportion of $\mathrm{CD} 4+\mathrm{T}$ cells that highly express CD25 (IL-2R $\alpha$-chain) on their surface and specifically express Foxp3 [49-53]. These CD4+CD25+Foxp3+Tregs act in a regulatory way by suppressing the activation of other $\mathrm{T}$ cells and control the immune responses induced by DCs in vivo $[54,55]$. It has especially been shown Tregs prevent CD8+T cell maturation by inhibiting $\mathrm{CD} 4+\mathrm{T}$ cells in tumor sites [56]. Therefore, the infiltration of CD4+CD25+Foxp3+Tregs is a major obstacle for developing effective antitumor treatments. So in this study, the observed higher infiltration of Tregs in tumor sites played an important role in the tampered anti-tumor effect of SLC treatment. Further study is followed.

In summary, our study indicates that mouse SLC gene transferred into liver cancer cell line by rAAV has strong $\mathrm{T}$ cell mediated anti-tumor effects. Our work also suggests a comprehensive immune therapy strategy applicable for solid tumors based on cooperative interaction of multiple effector cell types including Tregs. This strategy may overcome functional immune impairment observed in patients with advanced malignancy.

Acknowledgments This work has been supported by National Science Foundation of China (No. 30871312) and The National Basic Research Program of China (973 program), Grant Number 2011CB910700.

Open Access This article is distributed under the terms of the Creative Commons Attribution License which permits any use, distribution, and reproduction in any medium, provided the original author(s) and the source are credited.

\section{References}

1. Nagira M, Imai T, Hieshima K, Kusuda J, Ridanpaa M, Takagi S, Nishimura M, Kakizaki M, Nomiyama H, Yoshie O (1997) Molecular cloning of a novel human CC chemokine secondary lymphoid-tissue chemokine that is a potent chemoattractant for lymphocytes and mapped to chromosome 9p13. J Biol Chem 272:19518-19524

2. Hromas R, Kim CH, Klemsz M, Krathwohl M, Fife K, Cooper S, Schnizlein-Bick C, Broxmeyer HE (1997) Isolation and characterization of Exodus-2, a novel $\mathrm{C}-\mathrm{C}$ chemokine with a unique 37-amino acid carboxyl-terminal extension. J Immunol 159:2554-2558

3. Gunn MD, Tangemann K, Tam C, Cyster JG, Rosen SD, Williams LT (1998) A chemokine expressed in lymphoid high endothelial venules promotes the adhesion and chemotaxis of naive T lymphocytes. Proc Natl Acad Sci USA 95:258-263

4. Yoshida R, Nagira M, Kitaura M, Imagawa N, Imai T, Yoshie O (1998) Secondary lymphoid-tissue chemokine is a functional ligand for the $\mathrm{CC}$ chemokine receptor CCR7. J Biol Chem 273:7118-7122

5. Nagira M, Imai T, Yoshida R, Takagi S, Iwasaki M, Baba M, Tabira Y, Akagi J, Nomiyama H, Yoshie O (1998) A lymphocyte-specific CC chemokine, secondary lymphoid tissue chemokine (SLC), is a highly efficient chemoattractant for B cells and activated T cells. Eur J Immunol 28:1516-1523

6. Campbell JJ, Bowman EP, Murphy K, Youngman KR, Siani MA, Thompson DA, Wu L, Zlotnik A, Butcher EC (1998) 6-C-kine (SLC), a lymphocyte adhesion-triggering chemokine expressed by high endothelium, is an agonist for the MIP-3beta receptor CCR7. J Cell Biol 141:1053-1059

7. Willimann K, Legler DF, Loetscher M, Roos RS, Delgado MB, Clark-Lewis I, Baggiolini M, Moser B (1998) The chemokine SLC is expressed in T cell areas of lymph nodes and mucosal lymphoid tissues and attracts activated T cells via CCR7. Eur J Immunol 28:2025-2034

8. Pachynski RK, Wu SW, Gunn MD, Erle DJ (1998) Secondary lymphoid-tissue chemokine (SLC) stimulates integrin alpha 4 beta 7-mediated adhesion of lymphocytes to mucosal addressin cell adhesion molecule-1 (MAdCAM-1) under flow. J Immunol 161:952-956

9. Gunn MD, Kyuwa S, Tam C, Kakiuchi T, Matsuzawa A, Williams LT, Nakano H (1999) Mice lacking expression of secondary lymphoid organ chemokine have defects in lymphocyte homing and dendritic cell localization. J Exp Med 189:451-460

10. Kim CH, Pelus LM, Appelbaum E, Johanson K, Anzai N, Broxmeyer HE (1999) CCR7 ligands, SLC/6Ckine/Exodus2/ TCA4 and CKbeta-11/MIP-3beta/ELC, are chemoattractants for CD56(+)CD16(-) NK cells and late stage lymphoid progenitors. Cell Immunol 193:226-235

11. Chan VW, Kothakota S, Rohan MC, Panganiban-Lustan L, Gardner JP, Wachowicz MS, Winter JA, Williams LT (1999) Secondary lymphoid-tissue chemokine (SLC) is chemotactic for mature dendritic cells. Blood 93:3610-3616

12. Stein JV, Soriano SF, M'Rini C, Nombela-Arrieta C, de Buitrago GG, Rodriguez-Frade JM, Mellado M, Girard JP, Martinez AC (2003) CCR7-mediated physiological lymphocyte homing involves activation of a tyrosine kinase pathway. Blood 101:38-44

13. Kellermann SA, Hudak S, Oldham ER, Liu YJ, McEvoy LM (1999) The CC chemokine receptor-7 ligands 6Ckine and macrophage inflammatory protein-3 beta are potent chemoattractants for in vitroand in vivo-derived dendritic cells. J Immunol 162:3859-3864

14. Ueno T, Hara K, Willis MS, Malin MA, Hopken UE, Gray DH, Matsushima K, Lipp M, Springer TA, Boyd RL, Yoshie O, Takahama Y (2002) Role for CCR7 ligands in the emigration of newly generated $\mathrm{T}$ lymphocytes from the neonatal thymus. Immunity 16:205-218

15. Mori S, Nakano H, Aritomi K, Wang CR, Gunn MD, Kakiuchi T (2001) Mice lacking expression of the chemokines CCL21-ser and CCL19 (plt mice) demonstrate delayed but enhanced T cell immune responses. J Exp Med 193:207-218 
16. Forster R, Schubel A, Breitfeld D, Kremmer E, Renner-Muller I, Wolf E, Lipp M (1999) CCR7 coordinates the primary immune response by establishing functional microenvironments in secondary lymphoid organs. Cell 99:23-33

17. Soto H, Wang W, Strieter RM, Copeland NG, Gilbert DJ, Jenkins NA, Hedrick J, Zlotnik A (1998) The CC chemokine 6Ckine binds the CXC chemokine receptor CXCR3. Proc Natl Acad Sci USA 95:8205-8210

18. Warren P, Song W, Holle E, Holmes L, Wei Y, Li J, Wagner T, Yu X (2002) Combined HSV-TK/GCV and secondary lymphoid tissue chemokine gene therapy inhibits tumor growth and elicits potent antitumor CTL response in tumor-bearing mice. Anticancer Res 22:599-604

19. Sharma S, Yang SC, Hillinger S, Zhu LX, Huang M, Batra RK, Lin JF, Burdick MD, Strieter RM, Dubinett SM (2003) SLC/ CCL21-mediated anti-tumor responses require IFNgamma, MIG/ CXCL9 and IP-10/CXCL10. Mol Cancer 2:22

20. Tolba KA, Bowers WJ, Muller J, Housekneckt V, Giuliano RE, Federoff HJ, Rosenblatt JD (2002) Herpes simplex virus (HSV) amplicon-mediated codelivery of secondary lymphoid tissue chemokine and CD40L results in augmented antitumor activity. Cancer Res 62:6545-6551

21. Yang SC, Hillinger S, Riedl K, Zhang L, Zhu L, Huang M, Atianzar K, Kuo BY, Gardner B, Batra RK, Strieter RM, Dubinett SM, Sharma S (2004) Intratumoral administration of dendritic cells overexpressing CCL21 generates systemic antitumor responses and confers tumor immunity. Clin Cancer Res 10:2891-2901

22. During MJ, Samulski RJ, Elsworth JD, Kaplitt MG, Leone P, Xiao X, Li J, Freese A, Taylor JR, Roth RH, Sladek JR Jr, O'Malley KL, Redmond DE Jr (1998) In vivo expression of therapeutic human genes for dopamine production in the caudates of MPTP-treated monkeys using an AAV vector. Gene Ther 5:820-827

23. Bjorklund A, Kirik D, Rosenblad C, Georgievska B, Lundberg C, Mandel RJ (2000) Towards a neuroprotective gene therapy for Parkinson's disease: use of adenovirus, AAV and lentivirus vectors for gene transfer of GDNF to the nigrostriatal system in the rat Parkinson model. Brain Res 886:82-98

24. Kessler PD, Podsakoff GM, Chen X, McQuiston SA, Colosi PC, Matelis LA, Kurtzman GJ, Byrne BJ (1996) Gene delivery to skeletal muscle results in sustained expression and systemic delivery of a therapeutic protein. Proc Natl Acad Sci USA 93:14082-14087

25. Xu R, Sun X, Tse LY, Li H, Chan PC, Xu S, Xiao W, Kung HF, Krissansen GW, Fan ST (2003) Long-term expression of angiostatin suppresses metastatic liver cancer in mice. Hepatology 37:1451-1460

26. Lee HC, Kim SJ, Kim KS, Shin HC, Yoon JW (2000) Remission in models of type 1 diabetes by gene therapy using a single-chain insulin analogue. Nature 408:483-488

27. Su H, Joho S, Huang Y, Barcena A, Arakawa-Hoyt J, Grossman W, Kan YW (2004) Adeno-associated viral vector delivers cardiac-specific and hypoxia-inducible VEGF expression in ischemic mouse hearts. Proc Natl Acad Sci USA 101:16280-16285

28. Lollini PL, Forni G (1999) Specific and nonspecific immunity in the prevention of spontaneous tumours. Immunol Today 20:347-350

29. Mule JJ, Custer M, Averbook B, Yang JC, Weber JS, Goeddel DV, Rosenberg SA, Schall TJ (1996) RANTES secretion by gene-modified tumor cells results in loss of tumorigenicity in vivo: role of immune cell subpopulations. Hum Gene Ther 7:1545-1553

30. Dilloo D, Bacon K, Holden W, Zhong W, Burdach S, Zlotnik A, Brenner M (1996) Combined chemokine and cytokine gene transfer enhances antitumor immunity. Nat Med 2:1090-1095
31. Ploix C, Lo D, Carson MJ (2001) A ligand for the chemokine receptor CCR7 can influence the homeostatic proliferation of CD4 $\mathrm{T}$ cells and progression of autoimmunity. J Immunol 167:6724-6730

32. Banas B, Wornle M, Berger T, Nelson PJ, Cohen CD, Kretzler M, Pfirstinger J, Mack M, Lipp M, Grone HJ, Schlondorff D (2002) Roles of SLC/CCL21 and CCR7 in human kidney for mesangial proliferation, migration, apoptosis, and tissue homeostasis. J Immunol 168:4301-4307

33. Jang $M H$, Sougawa $N$, Tanaka $T$, Hirata $T$, Hiroi $T$, Tohya $K$, Guo Z, Umemoto E, Ebisuno Y, Yang BG, Seoh JY, Lipp M, Kiyono H, Miyasaka M (2006) CCR7 is critically important for migration of dendritic cells in intestinal lamina propria to mesenteric lymph nodes. J Immunol 176:803-810

34. Sharma S, Stolina M, Luo J, Strieter RM, Burdick M, Zhu LX, Batra RK, Dubinett SM (2000) Secondary lymphoid tissue chemokine mediates $\mathrm{T}$ cell-dependent antitumor responses in vivo. J Immunol 164:4558-4563

35. Vicari AP, Ait-Yahia S, Chemin K, Mueller A, Zlotnik A, Caux C (2000) Antitumor effects of the mouse chemokine 6Ckine/SLC through angiostatic and immunological mechanisms. J Immunol 165:1992-2000

36. Kirk CJ, Hartigan-O'Connor D, Nickoloff BJ, Chamberlain JS, Giedlin M, Aukerman L, Mule JJ (2001) T cell-dependent antitumor immunity mediated by secondary lymphoid tissue chemokine: augmentation of dendritic cell-based immunotherapy. Cancer Res 61:2062-2070

37. Nomura T, Hasegawa H, Kohno M, Sasaki M, Fujita S (2001) Enhancement of anti-tumor immunity by tumor cells transfected with the secondary lymphoid tissue chemokine EBI-1-ligand chemokine and stromal cell-derived factor-1alpha chemokine genes. Int J Cancer 91:597-606

38. Sharma S, Stolina M, Zhu L, Lin Y, Batra R, Huang M, Strieter R, Dubinett SM (2001) Secondary lymphoid organ chemokine reduces pulmonary tumor burden in spontaneous murine bronchoalveolar cell carcinoma. Cancer Res 61:6406-6412

39. Flanagan K, Moroziewicz D, Kwak H, Horig H, Kaufman HL (2004) The lymphoid chemokine CCL21 costimulates naive T cell expansion and Th1 polarization of non-regulatory $\mathrm{CD} 4+\mathrm{T}$ cells. Cell Immunol 231:75-84

40. Yamano T, Kaneda Y, Huang S, Hiramatsu SH, Hoon DS (2006) Enhancement of immunity by a DNA melanoma vaccine against TRP2 with CCL21 as an adjuvant. Mol Ther 13:194-202

41. Hisada M, Yoshimoto T, Kamiya S, Magami Y, Miyaji H, Yoneto T, Tamada K, Aoki T, Koyanagi Y, Mizuguchi J (2004) Synergistic antitumor effect by coexpression of chemokine CCL21/SLC and costimulatory molecule LIGHT. Cancer Gene Ther 11:280-288

42. Kaplitt MG, Leone P, Samulski RJ, Xiao X, Pfaff DW, O’Malley KL, During MJ (1994) Long-term gene expression and phenotypic correction using adeno-associated virus vectors in the mammalian brain. Nat Genet 8:148-154

43. Zhang F, Chen CL, Qian JQ, Yan JT, Cianflone K, Xiao X, Wang DW (2005) Long-term modifications of blood pressure in normotensive and spontaneously hypertensive rats by gene delivery of rAAV-mediated cytochrome P450 arachidonic acid hydroxylase. Cell Res 15:717-724

44. Yang SC, Batra RK, Hillinger S, Reckamp KL, Strieter RM, Dubinett SM, Sharma S (2006) Intrapulmonary administration of CCL21 gene-modified dendritic cells reduces tumor burden in spontaneous murine bronchoalveolar cell carcinoma. Cancer Res 66:3205-3213

45. Ochsenbein AF, Klenerman P, Karrer U, Ludewig B, Pericin M, Hengartner H, Zinkernagel RM (1999) Immune surveillance against a solid tumor fails because of immunological ignorance. Proc Natl Acad Sci USA 96:2233-2238 
46. Ochsenbein AF, Sierro S, Odermatt B, Pericin M, Karrer U, Hermans J, Hemmi S, Hengartner H, Zinkernagel RM (2001) Roles of tumour localization, second signals and cross priming in cytotoxic T-cell induction. Nature 411:1058-1064

47. Wick M, Dubey P, Koeppen H, Siegel CT, Fields PE, Chen L, Bluestone JA, Schreiber H (1997) Antigenic cancer cells grow progressively in immune hosts without evidence for $\mathrm{T}$ cell exhaustion or systemic anergy. J Exp Med 186:229-238

48. Hanson HL, Donermeyer DL, Ikeda H, White JM, Shankaran V, Old LJ, Shiku H, Schreiber RD, Allen PM (2000) Eradication of established tumors by CD8+T cell adoptive immunotherapy. Immunity 13:265-276

49. Sakaguchi S, Sakaguchi N, Asano M, Itoh M, Toda M (1995) Immunologic self-tolerance maintained by activated $\mathrm{T}$ cells expressing IL-2 receptor alpha-chains (CD25). Breakdown of a single mechanism of self-tolerance causes various autoimmune diseases. J Immunol 155:1151-1164

50. O'Garra A, Vieira P (2004) Regulatory T cells and mechanisms of immune system control. Nat Med 10:801-805
51. Piccirillo CA, Thornton AM (2004) Cornerstone of peripheral tolerance: naturally occurring $\mathrm{CD} 4+\mathrm{CD} 25+$ regulatory $\mathrm{T}$ cells. Trends Immunol 25:374-380

52. Hori S, Nomura T, Sakaguchi S (2003) Control of regulatory $T$ cell development by the transcription factor Foxp3. Science 299:1057-1061

53. Khattri R, Cox T, Yasayko SA, Ramsdell F (2003) An essential role for Scurfin in CD4+CD25+T regulatory cells. Nat Immunol 4:337-342

54. Shevach EM (2001) Certified professionals: CD4(+)CD25(+) suppressor T cells. J Exp Med 193:F41-F46

55. Oldenhove G, de Heusch M, Urbain-Vansanten G, Urbain J, Maliszewski C, Leo O, Moser M (2003) CD4+CD25+regulatory T cells control $\mathrm{T}$ helper cell type 1 responses to foreign antigens induced by mature dendritic cells in vivo. J Exp Med 198:259-266

56. Chaput N, Darrasse-Jeze G, Bergot AS, Cordier C, Ngo-Abdalla S, Klatzmann D, Azogui O (2007) Regulatory T cells prevent CD8 T cell maturation by inhibiting CD4 Th cells at tumor sites. J Immunol 179:4969-4978 